\title{
Bartonella infections in three species of Microtus: prevalence and genetic diversity, vertical transmission and the effect of concurrent Babesia microti infection on its success
}

Katarzyna Tołkacz'1, Mohammed Alsarraf', Maciej Kowalec', Dorota Dwużnik', Maciej Grzybek², Jerzy M. Behnke ${ }^{3}$ and Anna Bajer ${ }^{1 *}$

\begin{abstract}
Background: Bartonella spp. cause persistent bacterial infections in mammals. Although these bacteria are transmitted by blood-feeding arthropods, there is also evidence for vertical transmission in their mammalian hosts. We aimed to determine: (i) the prevalence and diversity of Bartonella spp. in a Microtus spp. community; (ii) whether vertical transmission occurs from infected female voles to their offspring; (iii) the effect of concurrent Babesia microti infection on the success of vertical transmission of Bartonella; and (iv) the impact of congenital infection on pup survival.

Results: We sampled 124 Microtus arvalis, 76 Microtus oeconomus and 17 Microtus agrestis. In total, 115 embryos were isolated from 21 pregnant females. In the following year 11 pregnant females were kept until they had given birth and weaned their pups $(n=62)$. Blood smears and PCR targeting the Bartonella-specific rpoB gene fragment (333bp) were used for the detection of Bartonella. Bartonella DNA was detected in $66.8 \%(145 / 217)$ of the wild-caught voles. Bartonella infection was detected in 81.8\% (36/44) of pregnant female voles. Bartonella-positive individuals were identified among the embryos (47.1\%; 40/85) and in 54.8\% (34/62) of pups. Congenitally acquired Bartonella infections and co-infection with B. microti had no impact on the survival of pups over a 3-week period post partum. Among 113 Bartonella sequences, four species were detected: Bartonella taylorii, Bartonella grahamii, Bartonella doshiae and a Bartonella rochalimae-like genotype. Bartonella taylorii clade B was the dominant species in wild-caught voles (49\%), pregnant females (47\%), their embryos (85\%), dams (75\%) and pups (95\%).

Conclusions: High prevalence of Bartonella spp. infection maintained in Microtus spp. community is followed by a high rate of vertical transmission of several rodent species of Bartonella in three species of naturally infected voles, $M$. arvalis, M. oeconomus and M. agrestis. Congenitally acquired Bartonella infection does not affect the survival of pups. Co-infection with B. microti does not affect the effectiveness of the vertical transmission of Bartonella in voles. Bartonella taylorii clade B was found to be the dominant species in wild-caught voles, including pregnant females and dams, and in their offspring, and was also found to be the most successful in vertical transmission.
\end{abstract}

Keywords: Babesia microti, Bartonella, Congenital infection, Microtus, Poland, Vector-borne zoonotic diseases, Vertical transmission, Voles

\footnotetext{
* Correspondence: anabena@biol.uw.edu.pl

'Department of Parasitology, Institute of Zoology, Faculty of Biology,

University of Warsaw, 1 Miecznikowa Street, 02-096 Warsaw, Poland

Full list of author information is available at the end of the article
}

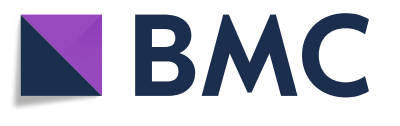

(c) The Author(s). 2018 Open Access This article is distributed under the terms of the Creative Commons Attribution 4.0 International License (http://creativecommons.org/licenses/by/4.0/), which permits unrestricted use, distribution, and reproduction in any medium, provided you give appropriate credit to the original author(s) and the source, provide a link to the Creative Commons license, and indicate if changes were made. The Creative Commons Public Domain Dedication waiver (http://creativecommons.org/publicdomain/zero/1.0/) applies to the data made available in this article, unless otherwise stated. 


\section{Background}

Bacteria of the genus Bartonella cause persistent infections in erythrocytes and endothelial cells of mammalian hosts. Infection may contribute to the development of an important vector-borne disease: bartonellosis [1, 2]. Of the 36 named and about 20 "Candidatus" species, 17 are recognized as causes of increasing numbers of human and animal bartonellosis cases [2]. Because bartonellosis is characterized by persistent intravascular infection, serious disease syndromes may develop, including endocarditis, myocarditis and a range of vascular pathologies [2]. During the last ten years, the number of confirmed Bartonella-derived endocarditis cases diagnosed in humans has increased, attributable in some measure to the increasing awareness of these bacteria by medical practitioners [3, 4].

Zoonotic bartonellosis in humans is associated with several species infecting cats and dogs (i.e. Bartonella henselae, Bartonella clarridgeiae, Bartonella rochalimae, Bartonella vinsonii berkhoffi) but also with several species (i.e. Bartonella doshiae, Bartonella elizabethae, Bartonella grahamii) for which different rodent species constitute the main hosts [5-7]. Many rodent species are important reservoir hosts of these bacteria, including mice (Apodemus and Peromyscus spp.) and voles (Myodes and Microtus spp.) [1, 7-11]. Prevalence of Bartonella infections in rodents differs, but may reach $60-70 \%$ or even $90 \%$ in susceptible host species [10, 12-21]. About 25 rodent-associated Bartonella spp. and genotypes have been described to date $[5,7,22]$ and this number is constantly increasing. Although these bacteria are transmitted by a range of blood-feeding arthropods, fleas are considered to be the main vectors among rodents [2, 7, 12, 23-26].

There is also evidence for efficient vertical transmission of bartonellae in different rodents. The first study on vertical transmission was conducted on naturally infected cotton rats (Sigmodon hispidus) and deer mice (Peromyscus leucopus) in the USA [27], and this established that this mode of transmission was possible and highly successful. Vertical transmission of Bartonella birtlesi has been experimentally demonstrated in BALB/ c mice in which $76 \%$ of fetal resorptions were culture positive for $B$. birtlesi, and vascular lesions were observed in the maternal placenta [28]. However, no bacteria were isolated from 58 viable pups born from infected mice in this study [28]. Recently, Bartonella DNA was detected in $69 \%$ of fetuses of Bartonella-infected wood mice (Apodemus sylvaticus) from the Barcelona region in Spain [29] and in one of 15 pups born to experimentally infected jirds [26]. In contrast to those studies, no congenital infections were recognized in bank voles Myodes glareolus in the UK [12]. Several cases of human congenital bartonellosis have been reported and attributed to different species of Bartonella $[30,31]$, including the case of a 22-day-old boy from
Peru [32]. All of the above findings indicate that further studies on vertical transmission of these vector-borne bacteria are still needed to enable a comprehensive epidemiological assessment of the risk of infection by this route.

In our previous studies in rodent hosts, we observed an interesting pattern of host age-related prevalence suggesting the existence of vertical transmission $[13,14,33$, 34]. In contrast to the expectation that the acquisition of vector-borne pathogens should increase with host age as a consequence of the associated increased risk of vector contact with increasing age, we often observed a reversed pattern, with the prevalence of Bartonella infection decreasing with host age, and this could not be explained simply by greater exposure of juveniles to ectoparasites. Our aim was to describe the Bartonella spp. infection and the possibility of vertical transmission of this parasite in the population of wild-living voles in Poland. We aimed to determine: (i) the prevalence and diversity of Bartonella spp. in a Microtus spp. community; (ii) whether vertical transmission occurs from infected female voles to their offspring; (iii) the effect of concurrent Babesia microti infection on the success of vertical transmission of Bartonella; and (iv) the impact of congenital infection on pup survival.

To achieve the aims, we determined the presence of Bartonella in embryos dissected from naturally infected voles, since this should completely eliminate the possibility of vector-borne transmission to the embryos. To eliminate the possibility that the tissues of the embryos may have been contaminated by maternal blood, we also maintained in captivity naturally infected pregnant female voles, completely deprived of ectoparasites, until a suitable period after parturition when individual sampling of the blood of the pups was possible. Thus we assessed the prevalence of congenitally transmitted Bartonella infection in the pups and evaluated the impact of congenital infection on pup survival. Finally, we identified the bacterial species infecting wild-caught voles and offspring through their distinct molecular signatures. The obtained results expanded the existing knowledge on the prevalence, vertical transmission and species composition of Bartonella in wild living rodents in Poland.

\section{Methods}

Field studies were conducted in the Mazury Lake District of north-eastern Poland (Urwitałt, near Mikołajki; $\left.53^{\circ} 48^{\prime} 50.25^{\prime \prime} \mathrm{N}, 21^{\circ} 39^{\prime} 7.17^{\prime \prime} \mathrm{E}\right)$, within an extensive forest and old field system adjacent to Lakes Śniardwy and Łuknajno. A detailed description of trapping sites is provided in Tolkacz et al. [35]. In short, three species of voles were live-trapped in different microhabitats extending up gentle hills (greatest elevation $5 \mathrm{~m}$ ) from two 
small ponds, giving enough height difference for a gradation in physical conditions and vegetation: from marshland (submerged during rainy weather; optimal habitat for the root vole, Microtus oeconomus) to dry grassland (preferable habitat of Microtus arvalis). Individuals of Microtus agrestis were trapped in the intermediate zones. Trapping took place in summer (August and early September) in 2013 and 2014. Traps were set for at least 5 consecutive nights. All animals $(n=217$; for details see Table 1 in [35]) were transported in their traps to the laboratory for inspection.

In 2013, the autopsies were carried out under terminal anaesthesia [35]. Voles were allocated to three age classes (juveniles, young adults and adults) based on body weight and nose-to-anus length together with reproductive condition (scrotal, semi-scrotal or non-scrotal for males; lactating, pregnant or receptive for females) [33]. Ectoparasites were removed and preserved in $99.8 \%$ methanol. A blood sample was taken from the heart (for direct preparation of two thin blood smears and storage in $0.001 \mathrm{M}$ EDTA for subsequent DNA extraction). Identification of the vole species was performed as described previously [35]. The upper (maxilla) and lower (mandible) jawbones of autopsied individuals were inspected to confirm the identity of the vole species based on the known dental formula for each, and especially to distinguish between juvenile individuals of M. oeconomus and $M$. agrestis [36]. We confirmed the species identity of each by examination of the lower molars $M_{1}$ and $M_{2}$ and the second upper molar $\left(\mathrm{M}^{2}\right)$ [36]. Embryos were isolated from the uterus, washed in sterile water and frozen at a temperature of $-20^{\circ} \mathrm{C}$.

In the summer of 2014, all captured voles were live-processed as described in Tolkacz et al. [35], including the removal of ectoparasites from anesthetized animals. A blood sample was taken from the tail tip of each vole (for blood smears, preservation in EDTA and DNA extraction). Then, males and juveniles were released near to their trapping points. Females suspected of being pregnant were transferred to individual clean sterile cages to establish a breeding colony of voles [35]. To prevent the development of ectoparasites (i.e. development of nymphs from engorged tick larvae), and to provide suitable housing conditions for voles, the cages were cleaned at least once per week. During handling, all voles from the breeding colony were inspected for ectoparasites in order to ensure vector-free conditions in the cages and animal house. No ectoparasites were noted at any time after initial caging. Females were kept at a constant temperature of $18{ }^{\circ} \mathrm{C}$, and with a 16 (day): 8 (night) light-dark photoperiod for at least 3 weeks to allow pregnancies to develop to term. Non-pregnant females were then released at their original trap lines. Pups were kept together with their dams for one month. In the third week of life we weighed the pups and collected blood samples from the tail tip. Pups and dams were then released at the trap lines at which the dams had been originally caught.

\section{Blood collection and DNA extraction}

Two blood smears were prepared from wild-caught voles and pups. Smears were air-dried, fixed in absolute methanol and stained with Diff Quick (Microptic SL, Barcelona, Spain) and Hemacolor (Merck, Darmstadt, Germany) staining kits, according to each manufacturer's instructions. Specific amplification of Bartonella DNA was used for the identification of infection in all adult voles (males and females), embryos and pups. Between 20 (from the live-processed voles) and $200 \mu \mathrm{l}$ (from the culled individuals) of whole blood were collected into $0.001 \mathrm{M}$ EDTA and frozen at a temperature of $-20{ }^{\circ} \mathrm{C}$ before DNA extraction. Embryos were isolated from the uterus and individually autopsied following two washes in sterile water, to minimize contamination with

Table 1 Prevalence of Bartonella spp. in three species of wild-caught Microtus voles. Numbers of pregnant females are shown in parentheses; \% of pregnant infected females are shown in square brackets

\begin{tabular}{|c|c|c|c|c|c|c|c|c|c|c|c|c|c|}
\hline \multirow[t]{2}{*}{ Year } & \multirow{2}{*}{$\begin{array}{l}\text { Infection } \\
\text { status }\end{array}$} & \multicolumn{3}{|c|}{ M. arvalis } & \multicolumn{3}{|c|}{ M. agrestis } & \multicolumn{3}{|c|}{ M. oeconomus } & \multicolumn{3}{|c|}{ Microtus spp. } \\
\hline & & $\pi$ & q & All & $\pi$ & q & All & $\pi$ & q & All & $\bar{\sigma}$ & $q$ & Total \\
\hline \multirow[t]{3}{*}{2013} & $\mathrm{Nl}$ & 8 & $8(5)$ & 16 & 4 & $2(2)$ & 6 & 4 & $1(1)$ & 5 & 16 & $11(8)$ & 27 \\
\hline & । & 12 & $27(16)$ & 39 & 5 & $3(1)$ & 8 & 8 & $6(4)$ & 14 & 25 & $36(21)$ & 61 \\
\hline & $\%$ infected & 60.0 & 77.1 [76.2] & 70.9 & 55.6 & 60.0 [33.3] & 57.1 & 66.7 & 85.7 [80.0] & 73.7 & 61.0 & 76.6 [72.4] & 69.3 \\
\hline \multirow[t]{3}{*}{2014} & $\mathrm{NI}$ & 12 & $6(0)$ & 18 & 1 & $0(0)$ & 1 & 12 & $14(0)$ & 26 & 25 & $20(0)$ & 45 \\
\hline & I & 21 & $30(10)$ & 51 & 0 & $2(0)$ & 2 & 13 & $18(5)$ & 31 & 34 & $50(15)$ & 84 \\
\hline & $\%$ infected & 63.6 & 83.3 [100.0] & 73.9 & 0.0 & $100.0[-]$ & 66.7 & 52.0 & 56.3 [100.0] & 54.4 & 57.6 & 71.4 [100.0] & 65.1 \\
\hline \multirow[t]{3}{*}{ Total } & $\mathrm{Nl}$ & 20 & $14(5)$ & 34 & 5 & $2(2)$ & 7 & 16 & $15(1)$ & 31 & 41 & $31(8)$ & 72 \\
\hline & I & 33 & $57(26)$ & 90 & 5 & $5(1)$ & 10 & 21 & $24(9)$ & 45 & 59 & $86(36)$ & 145 \\
\hline & $\%$ infected & 62.3 & 80.3 [83.9] & 72.6 & 50.0 & 71.4 [33.3] & 58.8 & 56.8 & 61.5 [90.0] & 59.2 & 59.0 & 73.5 [81.8] & 66.8 \\
\hline
\end{tabular}


maternal blood. We autopsied 115 embryos from 21 litters (17 obtained in 2013 and 4 obtained in 2014 from females that succumbed under anaesthesia) (Fig. 1). Hearts and lungs were isolated from embryos with sterile dissecting instruments. Genomic DNA was extracted from whole blood and organs using the DNAeasy Blood \& Tissue kit (Qiagen, Hilden, Germany) and stored at a temperature of $-20{ }^{\circ} \mathrm{C}$. The remaining 12 litters were too small to enable the isolation of specific internal organs [35].

\section{Microscopic examination}

Smears from all captured animals and pups were examined under oil immersion $(\times 1000$ magnification $)$ for parasitaemia estimation. A total of 200 fields of vision were scanned by experienced researchers and the number of infected RBC (iRBC) was recorded. Parasitaemia was expressed as the mean number of $i R B C / 200$ fields of vision.

\section{Molecular characterization}

The detection and genotyping of Bartonella species/ variants were performed by amplification and sequencing of the 333 bp gene fragment of RNA polymerase $\beta$-subunit $(r p o B)$ obtained in a single-step PCR or in a nested PCR (in the case of no or weak signal from the initial one-step PCR). The primers and thermal profile used in this study have been described previously $[15,37]$.
In the first step of the nested PCR, the 825 bp gene fragment of RNA polymerase $\beta$-subunit (rpoB) was amplified with specific primers: 1400F (5'-CGC ATT GGC TTA CTT CGT ATG-3') and 2300R (5'-GTA GAC TGA TTA GAA CGC TG-3') [37]. The PCR conditions included: $95^{\circ} \mathrm{C}$ for $5 \mathrm{~min}$, followed by 38 cycles of denaturation at $95{ }^{\circ} \mathrm{C}$ for $45 \mathrm{~s}$, annealing at $55^{\circ} \mathrm{C}$ for $45 \mathrm{~s}$, and elongation at $72{ }^{\circ} \mathrm{C}$ for $45 \mathrm{~s}$. Final elongation was at $72^{\circ}$ $\mathrm{C}$ for $7 \mathrm{~min}$, followed by a hold step at $4{ }^{\circ} \mathrm{C}$. The PCR reaction was performed in $1 \times$ PCR buffer, $1 \mathrm{U}$ Taq polymerase, $1 \mu \mathrm{M}$ of each primer and $2 \mu \mathrm{l}$ of the extracted DNA sample. Negative controls were performed in the absence of template DNA.

In the second step (nested reaction) and in the single-step PCR, the forward primer rpoF (5'-GCA C GA TT(C/T) GCA TCA TCA TTT TCC-3') and the reverse primer rpoR (5'-CGC ATT ATG GTC GTA TTT G TC C-3') were used [15]. The PCR conditions included: $95{ }^{\circ} \mathrm{C}$ for $5 \mathrm{~min}$, followed by 39 cycles of denaturation at $95{ }^{\circ} \mathrm{C}$ for $45 \mathrm{~s}$, annealing at $55^{\circ} \mathrm{C}$ for $45 \mathrm{~s}$, and elongation at $72{ }^{\circ} \mathrm{C}$ for $45 \mathrm{~s}$. Final elongation was at $72{ }^{\circ} \mathrm{C}$ for $7 \mathrm{~min}$, followed by a hold step at $4{ }^{\circ} \mathrm{C}$. The PCR reaction was performed in $1 \times$ PCR buffer, $1 \mathrm{U}$ Taq polymerase, $1 \mu \mathrm{M}$ of each primer and $2 \mu \mathrm{l}$ of the extracted DNA sample in the case of the single PCR. Nested PCR reactions were performed with different volumes of the first PCR product: 1 or $0.5 \mu \mathrm{l}$, or finally with $2 \mu \mathrm{l}$ of a 1:9 dilution in sterile water. In some cases, dilution of the first reaction product

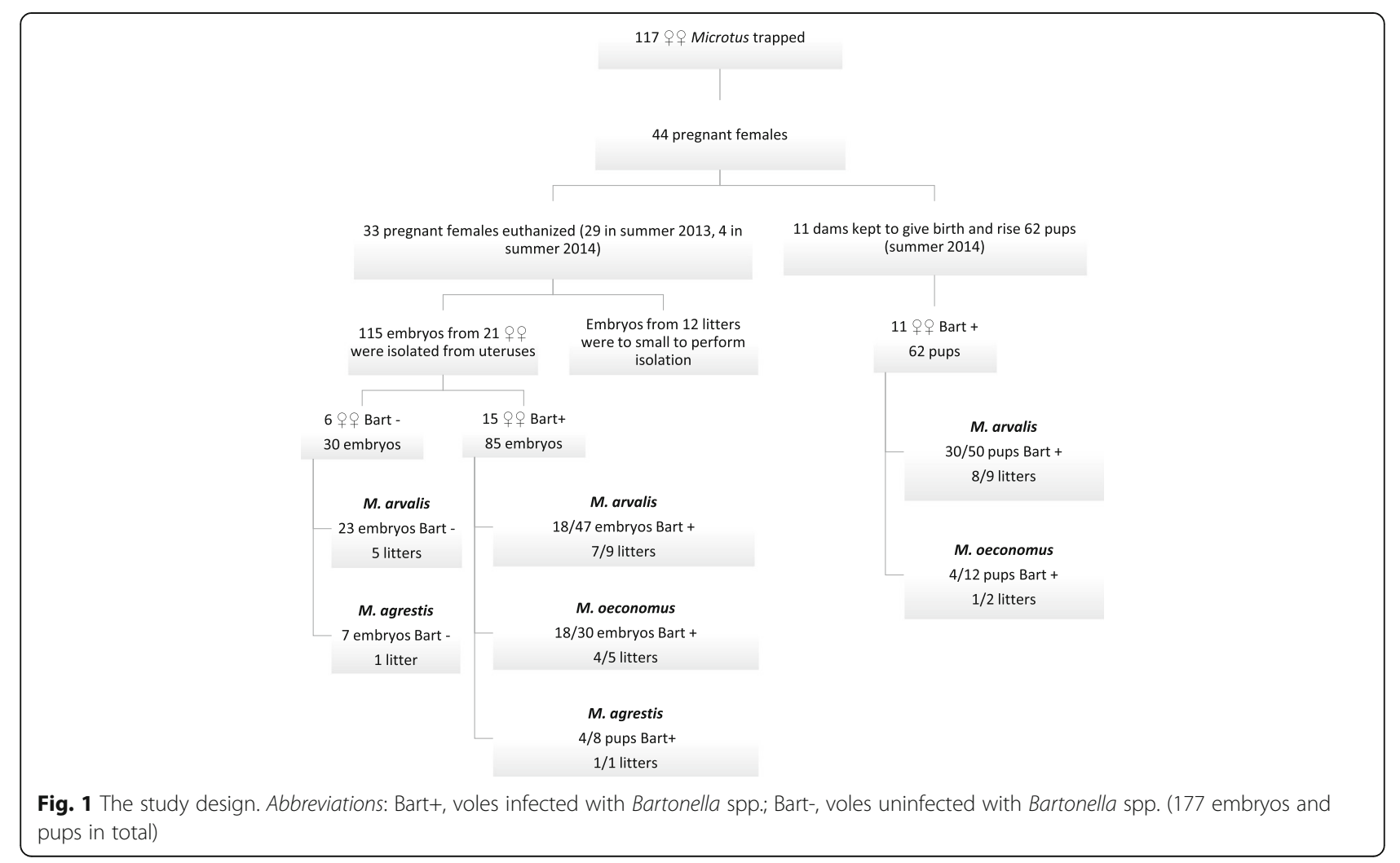


improved the output of nested reaction and the intensity of the bands. As positive controls, we used the genomic DNA of Bartonella acomydis extracted from wild rodents from Egypt [22].

PCR products were subjected to electrophoresis on a 1.5\% agarose gel, stained with Midori Green stain (Nippon Genetics GmbH, Düren, Germany). Selected PCR products from voles trapped in 2013 and 2014, all pregnant females and dams, and at least two embryos/ pups per litter (if available), were sequenced by a private company (Genomed S.A., Warsaw, Poland). DNA sequence alignments and analyses were conducted using MEGA v.7.0. Consensus sequences were compared with sequences deposited in the GenBank database (http:// www.ncbi.nlm.nih.gov/genbank/).

\section{Statistical analysis}

The statistical approach adopted has been documented comprehensively in our earlier publications [35, 38-40]. Prevalence (percentage of animals infected) was analyzed by maximum likelihood techniques based on log-linear analysis of contingency tables (in SPSS v. 21). The results are presented as percentages with 95\% confidence interval (CI), calculated with bespoke software based on the tables of Rohlf \& Sokal [41], by courtesy of F. S. Gilbert and J. M. Behnke from the University of Nottingham, UK. For analysis of the prevalence of Bartonella in wild-caught voles, we fitted prevalence of Bartonella infection as a binary factor and then year (two levels: 2013, 2014), host species (three levels: $M$. arvalis, $M$. oeconomus, $M$. agrestis), host age (three levels: juvenile, young adult, adult) and host sex (two levels: males and females) as factors. Subsequent analyses were carried out for each host species separately.

For analysis of the prevalence of Bartonella in embryos, we implemented 'female infection' as a binary factor (i.e. infected/uninfected mother). For analysis of the prevalence of Bartonella in pups, we implemented pup survival as a binary factor (dead $=0$ or alive $=1$ at the age of 3 weeks). In order to test the hypothesis that co-infection with Babesia microti in females/dams may facilitate congenital transmission of Bartonella to their embryos/pups, we fitted models with $B$. microti infection of female/dam and embryo/pup as an additional factor (coded as infected $=1$, uninfected $=0$ ). Beginning with the most complex model, involving all possible main effects and interactions, those combinations not contributing significantly to the explanation of variation in the data were eliminated stepwise, beginning with the highest-level interaction. A minimum sufficient model was then obtained, for which the likelihood ratio of $\chi^{2}$ was not significant, indicating that the model was sufficient in explaining the data.
General linear models (GLMs in SPSS v.21) were used for comparison of mean parameters (abundance of Bartonella, litter size, mean weight of pups, etc.), which are reported with standard errors of their means (SE). The abundance of Bartonella infection was calculated as the number of infected red blood cells (iRBC) in 200 fields of vision $(\times 1000$ magnification). When samples were only positive by PCR, an intensity of $0.001 \mathrm{iRBC} / 200$ fields was implemented into the quantitative statistical analysis.

The success of vertical transmission to each litter, calculated as the fraction of Bartonella-positive pups/litter was correlated with the litter size using the Spearman's rank correlation test (SPSS v. 21). Fisher's exact test (INSTAT software) was used to compare the percentage of infected pups between Bartonella-negative and Bartonella-positive females.

\section{Results}

Prevalence of Bartonella spp. in the community of voles In total, 217 voles of three species were trapped and sampled: 124 common voles, $M$. arvalis; 76 root voles, M. oeconomus; and 17 field voles, $M$. agrestis. Prevalence of Bartonella spp. infection by year of study, host species and sex is provided in Table 1. Prevalence was calculated by the PCR results and microscopical observation of blood smears. As these methods do not allow different bacterial species to be distinguished, we refer to 'Bartonella spp.' infection. In total, a positive product of the PCR reaction and microscopy was obtained for $66.8 \%$ (95\% CI: $62.4-71.0 \%$ ) of voles in the community. The highest prevalence of Bartonella spp. was detected in $M$. arvalis (72.6\%; 95\% CI: 65.2-79.0\%), lower and similar in $M$. oeconomus (59.2\%; 95\% CI: 47.1-70.6\%) and in $M$. agrestis $(58.8 \%$; 95\% CI: $35.0-80.4 \%)$, thus prevalence did not vary significantly between the three host species (Bartonella infection $\times$ host species: $X^{2}{ }_{2}=3.72, P=$ 0.156) (Table 1). Although minor differences in prevalence of Bartonella spp. between the two years of the study (Table 1) were observed, they were not significant (ns). However, prevalence of Bartonella spp. was higher in female voles (Bartonella infection $\times$ host sex: $X^{2}{ }_{1}$ $=5.12, P=0.024$; Table 1 ).

Age-related effects on prevalence differed among host species (Bartonella infection $\times$ host species $\times$ age class: $\left.X^{2}{ }_{4}=15.00, P=0.007\right)$. In $M$. arvalis, prevalence was high in juvenile voles (12/16, 75\%; 95\% CI: 50.0-91.0\%), highest in young adults $(19 / 19,100 \%$; $95 \%$ CI: $82.5-100.0 \%)$ but lowest in the oldest adults (59/89, 66.3\%; 95\% CI: $53.2-$ 77.7\%) (Bartonella infection $\times$ age class: $X^{2}{ }_{2}=13.92, P$ $=0.001)$. In $M$. oeconomus, prevalence increased gradually with host age $(40.0 \%, 57.0 \%$ and $63.5 \%$ in age class 1,2 and 3 , respectively) but the difference in prevalence 
between these age classes was not significant. In $M$. agrestis, the effect of age was not significant as our sample only included one juvenile individual of this species, which was found to be infected (100\%). Prevalence was 50\% in young adults and $60 \%$ in adult field voles (ns).

\section{Abundance of Bartonella spp. infection in the community of voles}

Mean abundance of Bartonella infection by year of study, host species and sex is provided in Table 2. The mean abundance of Bartonella infection, calculated for the three vole species combined, was low: $2.58 \pm 2.06$ iRBC/200 fields of vision.

Although there were some differences in the mean abundance of Bartonella spp. between host species, years of study, age classes and sexes, none of these factors affected abundance significantly. Numerically, abundance was highest among $M$. arvalis, lower in $M$. agrestis and the lowest in M. oeconomus, as observed for prevalence but the difference in abundance between host species was not significant (main effect of host species on abundance: $F_{(2,216)}=2.2, P=0.114$ ) (Table 2).

Similarly, host age did not have a significant effect on abundance, although the mean values for age classes followed the same sequence as for prevalence among $M$. arvalis and $M$. oeconomus: abundance of Bartonella was highest in age class 2 (young adults) and lowest in juvenile voles. In $M$. agrestis, we observed highest abundance in adult individuals and lowest in juveniles and young adults.

Table 2 Abundance of Bartonella spp. in wild-caught voles. Mean number of infected red blood cells (iRBC)/200 fields of vision \pm SE

\begin{tabular}{llll}
\hline Species & \multicolumn{1}{l}{ Year } & \\
\cline { 2 - 3 } & 2013 & 2014 & Total \\
\hline Microtus arvalis & & & \\
Males $(n=53)$ & $9.06 \pm 9.01$ & $2.28 \pm 8.02$ & $5.67 \pm 6.03$ \\
Females $(n=71)$ & $7.23 \pm 4.23$ & $6.06 \pm 4.87$ & $6.64 \pm 3.22$ \\
Combined sexes $(n=124)$ & $8.14 \pm 4.98$ & $4.17 \pm 4.69$ & $6.16 \pm 3.42$ \\
Microtus oeconomus & & & \\
Males $(n=37)$ & $0.55 \pm 1.5$ & $0.11 \pm 1.08$ & $0.28 \pm 0.89$ \\
Females $(n=39)$ & $0.11 \pm 1.27$ & $0.87 \pm 0.80$ & $0.49 \pm 0.75$ \\
Combined sexes $(n=76)$ & $0.29 \pm 0.98$ & $0.49 \pm 0.67$ & $0.40 \pm 0.58$ \\
Microtus agrestis & & & \\
Males $(n=10)$ & $3.14 \pm 3.73$ & $0.00 \pm 9.30$ & $2.10 \pm 3.98$ \\
Females $(n=7)$ & $0.00 \pm 4.39$ & $0.00 \pm 6.58$ & $0.00 \pm 3.68$ \\
Combined sexes $(n=17)$ & $1.26 \pm 3.03$ & $0.00 \pm 5.70$ & $0.90 \pm 2.71$ \\
Microtus spp. & & & \\
Males $(n=100)$ & & & \\
Females $(n=117)$ & $2.94 \pm 4.40$ & $1.02 \pm 4.50$ & $2.97 \pm 3.15$ \\
Combined sexes $(n=217)$ & $3.83 \pm 2.16$ & $1.34 \pm 3.51$ & $2.58 \pm 2.06$ \\
\hline
\end{tabular}

\section{Vertical transmission of Bartonella} Bartonella spp. infection in females and dams

Altogether 117 female voles were trapped, among which 44 were pregnant thus providing 26 litters (embryos and pups) from Bartonella-positive females. We excluded 12 litters because pregnancy was still at a very early stage and the embryos were too small to enable reliable isolation of fetal tissues. Six litters from Bartonella-negative mothers were available as a control group for analysis of vertical transmission (Fig. 1). The overall prevalence of Bartonella infection in the pregnant females was $81.8 \%$ (95\% CI: 65.2-91.6\%) (Table 1). The highest prevalence was noted in pregnant $M$. oeconomus voles (90\%; $95 \%$ CI: $55.4-99.5 \%$ ), then $83.9 \%$ (95\% CI: 70.8-92.4\%) in $M$. arvalis females, but only one female of three pregnant $M$. agrestis (33.3\%; 95\% CI: $1.7-86.5 \%)$ was found to be Bartonella-positive (Table 1, Fig. 1).

We were able to analyze the prevalence of infections in 115 embryos from 21 litters (including 15 litters from Bartonella-positive females and 6 litters from Bartonella-negative females; Fig. 1, Table 3).

Another 11 Bartonella-positive females were kept in captivity until parturition (host species and litter size are provided in Table 4).

\section{Detection of Bartonella in pregnant females and embryos (2013 and 2014)}

Prevalence of Bartonella spp. infections, as determined by PCR among the 115 embryos of the 21 females, was $34.8 \%$ (95\% CI: 28.0-42.2\%). No Bartonella DNA was detected in 30 embryos of the six Bartonella-negative females (5 M. arvalis and $1 \mathrm{M}$. agrestis), in comparison to $47.1 \%$ (40/85; 95\% CI: 34.5-59.9\%) of positive embryos recovered from 15 Bartonella-positive females (Fisher's exact test: $P<0.0001)$. Among Bartonella-positive pregnant females, nine were $M$. arvalis, five $M$. oeconomus and one $M$. agrestis (Fig. 1, Table 3). Bartonella-positive embryonic tissues (heart and lungs) were found in $80 \%$ (95\% CI: 53.4-94.3\%) of these litters.

The proportion of litters from Bartonella positive females, in which at least one embryo was Bartonella-positive, was similar among the three host species (Fig. 1, ns). However, the proportion of Bartonella-positive embryos carried by Bartonella positive females differed among the three host species (Fig. $1 ; X_{2}^{2}=11.92, P$ $=0.003)$. Among nine Bartonella-positive females of $M$. arvalis, positive embryos were identified in $77.7 \%$ (95\% CI: 44.2-95.9\%) of litters but the overall prevalence among embryos was 38.3\% (95\% CI: 22.9-56.0\%) (Fig. 1, Table 3). Bartonella DNA was detected in $80 \%$ (95\% CI: $34.3-99.0 \%$ ) of litters and 60\% (95\% CI: 41.6-76.4\%) of embryos of five Bartonella-positive M. oeconomus. In the one litter of the Bartonella-positive M. agrestis female, $50 \%$ (95\% CI: 19.3-80.7\%) of embryos were 
Table 3 Evidence for vertical transmission and genotype identity of Bartonella spp. in embryos isolated from female voles in 2013 and 2014

\begin{tabular}{|c|c|c|c|c|c|c|}
\hline \multirow{2}{*}{$\begin{array}{l}\text { ID of pregnant } \\
\text { female }\end{array}$} & \multirow[t]{2}{*}{ Host species } & \multirow{2}{*}{$\begin{array}{l}\text { No. of embryos } \\
\text { in litter }\end{array}$} & \multirow{2}{*}{$\begin{array}{l}\text { No. of embryos } \\
\text { infected with } \\
\text { Bartonella spp. in } \\
\text { litter }\end{array}$} & \multirow{2}{*}{$\begin{array}{l}\% \text { of infected } \\
\text { embryos }\end{array}$} & \multicolumn{2}{|l|}{ Bartonella strain } \\
\hline & & & & & In positive female & No. of genotyped embryos \\
\hline $2013 / 3$ & M. arvalis & 7 & 1 & 14.3 & nd & $1 \times$ B. taylorii (clade B) \\
\hline $2013 / 21$ & M. arvalis & 6 & 4 & 66.7 & $\begin{array}{l}\text { B. taylorii (clade B) }+B \text {. } \\
\text { rochalimae-like }\end{array}$ & $\begin{array}{l}2 \times \text { B. rochalimae-like }+ \text { B. } \\
\text { taylorii (clade B); } 1 \times B \text {. taylori } \\
\text { (clade B) }\end{array}$ \\
\hline $2013 / 36$ & M. agrestis & 8 & 4 & 50.0 & B. taylorii (clade B) & $3 \times$ B. taylorii (clade B) \\
\hline 2013/37 & M. arvalis & 5 & 3 & 60.0 & B. taylorii (clade B) & $3 \times$ B. taylorii (clade B) \\
\hline 2013/41 & M. arvalis & 6 & 2 & 33.3 & B. taylorii (clade A) & $1 \times$ B. taylorii (clade B) \\
\hline $2013 / 45$ & M. arvalis & 2 & 1 & 50.0 & B. grahamii & $1 \times$ B. taylorii (clade B) \\
\hline $2013 / 63$ & M. oeconomus & 5 & 0 & 0 & B. taylorii (clade B) & nd \\
\hline 2013/70 & M. oeconomus & 6 & 1 & 16.7 & B. grahamii & $1 \times$ B. taylorii (clade B) \\
\hline 2013/72 & M. arvalis & 6 & 0 & 0 & B. taylorii (clade A) & nd \\
\hline 2013/78 & M. arvalis & 7 & 0 & 0 & B. taylorii (clade B) & nd \\
\hline 2013/80 & M. arvalis & 4 & 3 & 75.0 & $\begin{array}{l}\text { B. taylorii (clade B) }+B \text {. } \\
\text { grahamii }\end{array}$ & $3 \times$ B. taylorii (clade B) \\
\hline $2014 / 19$ & M. oeconomus & 7 & 7 & 100 & B. grahamii & $2 \times B$. grahamii \\
\hline 2014/44 & M. oeconomus & 6 & 6 & 100 & B. grahamii & $n d^{*}$ \\
\hline $2014 / 68$ & M. oeconomus & 6 & 4 & 66.7 & $\begin{array}{l}\text { B. taylorii (clade B) }+B \text {. } \\
\text { doshiae }\end{array}$ & $4 \times$ B. taylorii (clade B) \\
\hline $2014 / 155$ & M. arvalis & 4 & 4 & 100 & nd & $3 \times$ B. taylorii (clade B) \\
\hline Total & $\begin{array}{l}15 \text { (9 Ma; } 5 \\
\text { Mo; } 1 \text { Mag) }\end{array}$ & $\begin{array}{l}85 \text { (47 Ma;30 } \\
\text { Mo; } 8 \text { Mag) }\end{array}$ & $\begin{array}{l}40 \text { (18 Ma; } 18 \\
\text { Mo; } 4 \text { Mag) }\end{array}$ & $\begin{array}{l}47.1 \%(38.3 \% \text { in } \\
M a ; 60.0 \% \text { in } M o ; \\
50.0 \% \text { in Mag) }\end{array}$ & $\begin{array}{l}16 \text { Bartonella spp. (2 B. } \\
\text { taylorii clade A; } 7 \text { B. } \\
\text { taylorii clade B; } 5 \text { B. } \\
\text { grahamii; } 1 \text { B. doshiae; } \\
1 \text { B. rochalimae-like) }\end{array}$ & $\begin{array}{l}27 \text { Bartonella spp. ( } 23 \text { B. } \\
\text { taylorii clade B; } 2 \text { B. grahamii } \\
2 \text { B. rochalimae-like) }\end{array}$ \\
\hline
\end{tabular}

Abbreviations: nd, not done; nd*, not done because of a weak signal; Ma, Microtus arvalis; Mo, Microtus oeconomus; Mag, Microtus agrestis

Bartonella-positive. Thus, not all embryos carried by infected females were positive for Bartonella, and the success of vertical transmission (fraction of positive embryos) of Bartonella spp. differed between litters even within host species: in three litters from infected mothers no positive embryos were identified, in another three all tested embryos were Bartonella-positive and prevalence of Bartonella spp. was within the range 14$75 \%$ for the remaining nine litters.

\section{Detection of Bartonella in dams and pups maintained in vector-free conditions (2014)}

In the second year, Bartonella DNA was detected in $54.8 \%$ (95\% CI: 43.9-65.3\%) of pups born to 11 Bartonella-positive dams (Fig. 1, Table 4). In two litters from M. oeconomus dams, 33.3\% (95\% CI: 12.3-63.0\%) of pups were positive, in comparison to $60 \%$ (95\% CI: $45.0-72.2 \%)$ positive pups from nine $M$. arvalis dams (Table 4, ns).

Among the 9 litters from $M$. arvalis dams, Bartonella-positive pups were found in 8 litters (89\%; 95\% CI: 55.7-99.4\%) and among positive litters, the percentage of Bartonella-positive pups varied within the range 14100\% (Table 4).

There was no correlation between the proportion of Bartonella-positive pups in a litter and litter size (Table 4, ns). There was also no significant difference between male and female pups born from infected dams: $55.2 \%(16 / 29$; 95\% CI: $36.0-72.8 \%)$ of males and $57.1 \%(12 / 21 ; 95 \% \mathrm{CI}$ : 35.4-76.7\%) of females were infected with Bartonella spp.

The abundance of Bartonella spp. was calculated by microscopical observation of blood smears of $44 M$. arvalis and $6 \mathrm{M}$. oeconomus pups. The mean abundance of Bartonella in blood smears collected from offspring of infected dams was $1.61 \pm 0.35$, but this was more than twice as high in $M$. oeconomus compared with $M$. arvalis pups $(2.5 \pm$ 0.67 and $0.72 \pm 0.24$, respectively; main effect of host species on Bartonella abundance: $\left.F_{(1,49)}=6.33, P=0.015\right)$.

\section{Effect of $B$. microti infection on vertical transmission of Bartonella}

In our previous study [35] on the same samples we provided evidence for a high rate of vertical transmission of $B$. microti in wild voles. In the minimal sufficient model 
Table 4 Evidence for vertical transmission and genotypes of B. taylorii in pups delivered by female voles captured in 2014

\begin{tabular}{|c|c|c|c|c|c|c|}
\hline \multirow{2}{*}{$\begin{array}{l}\text { ID of } \\
\text { pregnant } \\
\text { female }\end{array}$} & \multirow[t]{2}{*}{ Host species } & \multirow{2}{*}{$\begin{array}{l}\text { No. of pups } \\
\text { in litter }\end{array}$} & \multirow{2}{*}{$\begin{array}{l}\text { No. of pups } \\
\text { infected with } \\
\text { Bartonella spp. } \\
\text { in litter }\end{array}$} & \multirow{2}{*}{$\begin{array}{l}\% \text { of infected } \\
\text { pups }\end{array}$} & \multicolumn{2}{|l|}{ Bartonella strain } \\
\hline & & & & & In positive dams & No. of genotyped pups \\
\hline $2014 / 25$ & M. arvalis & 6 & 5 & 83.3 & nd & $3 \times$ B. taylorii (clade B) \\
\hline $2014 / 34$ & M. arvalis & 5 & 5 & 100 & B. taylorii (clade B) & $3 \times$ B. taylorii (clade B) \\
\hline $2014 / 59$ & M. arvalis & 5 & 5 & 100 & nd & $3 \times$ B. taylorii (clade B) \\
\hline $2014 / 65$ & M. arvalis & 6 & 6 & 100 & B. taylorii (clade B) & $3 \times$ B. taylorii (clade B) \\
\hline $2014 / 74^{a}$ & M. oeconomus & 6 & 0 & 0 & B. taylorii (clade B) & nd \\
\hline 2014/77 & M. oeconomus & 6 & 4 & 66.7 & nd & $3 \times$ B. taylorii (clade B) \\
\hline $2014 / 107^{\mathrm{a}}$ & M. arvalis & 6 & 6 & 100 & B. taylorii (clade B) & $3 \times$ B. taylorii (clade B) \\
\hline 2014/112 & M. arvalis & 5 & 0 & 0 & B. taylorii (clade A) & nd \\
\hline $2014 / 126$ & M. arvalis & 7 & 1 & 14.3 & B. taylorii (clade A) & $1 \times$ B. taylorii (clade A) \\
\hline 2014/130 & M. arvalis & 4 & 1 & 25 & B. taylorii (clade B) & $1 \times$ B. taylorii (clade B) \\
\hline 2014/131 & M. arvalis & 6 & 1 & 16.7 & B. taylorii (clade B) & $1 \times$ B. taylorii (clade B) \\
\hline Total & $11(9 \mathrm{Ma} ; 2 \mathrm{Mo})$ & 62 (50 Ma; $12 \mathrm{Mo})$ & 34 (30 Ma; 4 Mo) & $\begin{array}{l}54.8 \%(60 \% \text { in } M a ; \\
33 \% \text { in } M o)\end{array}$ & $\begin{array}{l}2 \text { B. taylorii clade A (2 } \\
\text { Ma); } 6 \text { B. taylorii clade } \\
\text { B (5 Ma+1 Mo) }\end{array}$ & $\begin{array}{l}1 \text { B. taylorii clade A (1 } \\
\text { Ma); } 20 \text { B. taylorii clade } \\
\text { B (18 Ma + } 3 \text { Mo) }\end{array}$ \\
\hline
\end{tabular}

${ }^{\text {a }}$ Pups died after birth

Abbreviations: nd, not done; Ma, Microtus arvalis; Mo, Microtus oeconomus

derived from analysis of a model that included $B$. microti infection, only the presence of Bartonella infection in females/dams had a significant effect on Bartonella infection in embryos/pups $\left(\chi_{1}^{2}=16.89, P<0.001\right)$. Babesia infection in females/dams had no effect: the success of vertical transmission of Bartonella was 32.4\% (12/37; 95\% CI: 19.4-47.9\%) in embryos/pups of Babesia-negative females/dams and 44.3\% (62/140; 95\% CI: 36.4$52.5 \%$ ) in embryos/pups of Babesia-positive females/ dams, and the difference was not significant. Focusing on the infection status of offspring, we correlated the success of vertical transmission of Babesia in the litters (fraction of Babesia-infected litter) with the success of vertical transmission of Bartonella in the litter (fraction of Bartonella-infected litter), for offspring of co-infected females/dams $(n=10)$, but no positive correlation was found. Finally, we tested a model for the prevalence of Bartonella and Babesia in embryos/pups, but again, no significant association was found.

\section{Influence of congenitally acquired Bartonella infection on litter size, body mass and survival of pups}

Two litters (6 pups of M. arvalis, 6 pups of M. oeconomus) died 1-2 days after birth. Both $M$. arvalis pups and dam (ID: 2014/107) were Bartonella-positive by PCR (Table 4). In the second litter, no positive pups were delivered by the Bartonella-positive M. oeconomus dam (ID: 2014/74; Fig. 1, Table 4).

All the other pups delivered by 9 Bartonella-positive dams (28 Bartonella-positive and 22 Bartonella-negative pups; Table 4) survived until the end of the experiment.
Thus the mortality of pups was $17.6 \%(6 / 34 ; 95 \%$ CI: $8.8-$ $31.6 \%$ ) among Bartonella-positive and 21.4\% (6/28; 95\% CI: 9.8-40.9\%) among Bartonella-negative pups (ns).

The effect of Bartonella infection of the dam on the litter size could not be reliably analyzed as there were no litters from Bartonella-negative dams.

We also tested the effect of congenital Bartonella infection on the weight of pups at the age of three weeks in a model controlling also for host species and sex. Although the mean weight of $M$. oeconomus pups was significantly higher than for $M$. arvalis pups: $17.56 \pm 1.07$ and $15.12 \pm 0.52 \mathrm{~g}$, respectively (main effect of host species on body mass of pups: $\left.F_{(1,49)}=5.31, P=0.027\right)$, no impact of Bartonella infection was found (ns). The mean weight was similar for Bartonella-positive and Bartonel$l a$-negative pups (16.68 \pm 0.73 and $15.45 \pm 0.71 \mathrm{~g})(\mathrm{ns})$.

\section{Genotyping of Bartonella spp. isolates from wild-caught voles and congenitally acquired infections}

We obtained 113 Bartonella sequences from 108 voles (62 adult voles and 46 embryos and pups), including 5 voles for which two different sequences were obtained in independent sequencing events (female nos. 2013/21, $2013 / 80,2016 / 68$ and two embryos from the first female: nos. 2013/21/3 and 2013/21/5; Table 3). Altogether 113 (67 M. arvalis, $35 \mathrm{M}$. oeconomus and $11 \mathrm{M}$. agrestis) Bartonella rpoB sequences were analyzed. Among these, 65 were derived from naturally infected voles, including pregnant females and dams $(31 \mathrm{M}$. arvalis, $26 \mathrm{M}$. oeconomus and $8 \mathrm{M}$. agrestis) and 48 were obtained from embryos or pups (36 M. arvalis, 9 M. oeconomus and 3 
$M$. agrestis). Selected representative sequences (including "mother" isolates starting with " $\mathrm{M}$ " and embryos/ pups isolates marked with mother " $M$ " and offspring "D" numbers) are presented on the phylogenetic tree in Fig. 2 and are deposited in the GenBank database (Additional file 1: Table S1).

Our sequences grouped into four distinct clades representing different species (Fig. 2, Tables 3 and 4). The most common species were B. taylorii $(89 / 113,79 \%)$ and then B. grahamii (19/113, 17\%). Additionally, two sequences of $B$. doshiae were identified. We also identified three sequences of a $B$. rochalimae-like variant (two in embryos and another one from their mother, M. arvalis; Table 3).

Among the $B$. taylorii sequences, two main genotypes were found in wild-caught voles, pregnant females and embryos, dams and their pups, both previously described from small rodents from the study area [15]. One genotype was identical (100\% homology) with B. taylorii clade A (GenBank: GU338926, GU338929) isolated from $M$. oeconomus and $M$. arvalis, respectively, from the Mazury Lake District. The second genotype was most similar (99-100\% of homology) to B. taylorii clade B (GenBank: GU338928, GU338931), previously isolated from bank vole $M$. glareolus and $M$. arvalis, respectively, from the Mazury Lake District [15] (Fig. 2). Two B. doshiae sequences were obtained from wild-caught voles, from $M$. arvalis and $M$. oeconomus displaying highest similarity (98-100\%) to B. doshiae from $M$. arvalis (GenBank: GU338939) from the study area [15]. A representative sequence of $B$. doshiae has been deposited in GenBank under the accession number MF357900.

Three sequences were obtained (from a $M$. arvalis female and two embryos) which showed highest similarity (98-99\%) to a unique Bartonella sequence found in $M$. glareolus in France (GenBank: JX846416). These sequences constituted a sister group to the B. rochalimae sequences obtained from clinical cases in South and North America. We thus consider them to be a B. rochalimaelike variant (Fig. 2); this sequence has been deposited in GenBank under the accession number MG839175.

The B. taylorii clade B genotype was dominant among wild-caught voles $(32 / 65,49 \%)$, pregnant females $(7 / 15$, $47 \%)$ and their embryos $(23 / 27,85 \%)$ and also among dams $(6 / 8,75 \%)$ and their pups $(20 / 21,95 \%)$ (Tables 3 and 4 ), and altogether $66 \%$ of the sequenced isolates corresponded to this genotype.

Bartonella grahamii was identified in 17 wild-caught voles (17/65, 26\%) (including five pregnant females: 5/ $15,33 \%)$ and in $7.4 \%(2 / 27)$ of embryos (Tables 3 and 4 ) but was not found in any of the dams or their pups (Tables 3 and 4), so altogether it was found in $17 \%$ of the sequenced isolates.

The B. taylorii clade A genotype was identified among wild-caught voles $(13 / 65,20 \%)$, in pregnant females $(2 /$
$15,13 \%)$ but not in any of their embryos, among dams $(2 / 8,25 \%)$ and in one pup $(1 / 21,5 \%)$ (Tables 3 and 4$)$, and altogether $12 \%$ of the sequenced isolates were of this genotype.

Among 65 Bartonella sequences obtained from wild-caught voles, 31 were from $M$. arvalis, 26 from M. oeconomus and 8 from $M$. agrestis. The B. taylorii clade B genotype was identified in $45 \%$ of sequences derived from $M$. arvalis (2 from males and 12 from females), in $50 \%$ of sequences derived from $M$. oeconomus (5 from males and 8 from females) and in $63 \%$ of sequences derived from $M$. agrestis (3 from males and 2 from females).

The B. taylorii clade A genotype was identified in $29 \%$ of isolates from $M$. arvalis ( 2 from males and 7 from females), in $4 \%$ of sequences derived from $M$. oeconomus ( 1 from a male) and in three sequences from $M$. agrestis ( 1 from a male and 2 from females).

Bartonella grahamii was identified in 19\% of isolates from $M$. arvalis ( 2 from males and 4 from females) and in $42 \%$ of sequences derived from $M$. oeconomus ( 4 from males and 7 from females).

Bartonella doshiae was identified in two female voles (M. arvalis and M. oeconomus-co-infection with B. taylorii clade $B$ ) and the $B$. rochalimae-like variant was found in one pregnant $M$. arvalis female (co-infection with B. taylorii clade B).

The final step was the correlation of Bartonella genotypes infecting mother voles and their corresponding offspring. Sequences of appropriate quality were obtained for 15 pairs. In 12 cases the same species and genotypes were identified in females/dams and their embryos/pups (Tables 3, 4 and Fig. 2: isolates from mothers "Mnn" and offspring "MnnDnn" grouped on the same branches). In one case (female 2013/21) two genotypes (B. taylorii clade B and the B. rochalimae-like variant) were identified in one individual. In this litter two embryos were co-infected with the $B$. rochalimae-like variant and with $B$. taylorii clade $B$, but the third embryo was only infected with B. taylorii clade B.

Only in three cases were different genotypes found in female-embryo pairs (Table 3 ). In three cases the B. taylorii clade B genotype was isolated from embryos, although B. grahamii (2 cases) or B. taylorii clade A were identified in their mothers.

Thus, the dominant Bartonella genotype identified in offspring was B. taylorii clade B, which was found in $85 \%$ of 27 embryos and in $95 \%$ of 21 pups. There were two other females co-infected concurrently with two Bartonella species, but in each of these cases only one of the genotypes was found in the offspring's tissues (females 2013/80 and 2014/68; Table 3). 


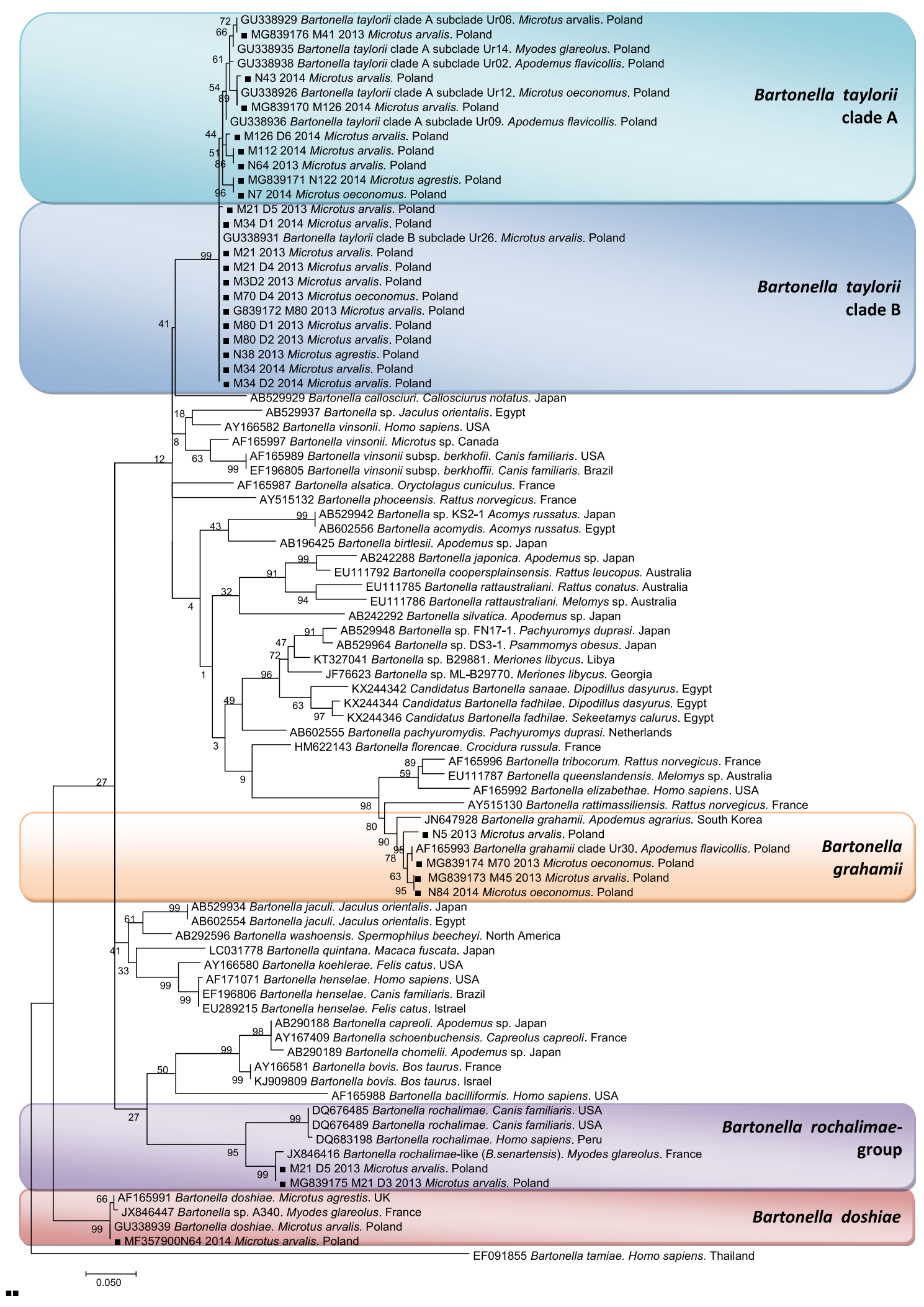

Fig. 2 (See legend on next page.) 
(See figure on previous page.)

Fig. 2 The phylogenetic tree of Bartonella spp., based on a fragment of the rpoB gene, was inferred using the maximum likelihood method and a Hasegawa-Kishino-Yano $(\mathrm{G}+\mathrm{I})$ model. The percentage of replicate trees in which the associated taxa clustered together in the bootstrap test (1000 replicates) are shown next to the branches. The analysis was based on 87 nucleotide sequences. All positions containing gaps and missing data were eliminated. Evolutionary analyses were conducted in MEGA7.0. Black squares indicate the newly generated sequences of the present study

\section{Discussion}

In the present study, we report a high prevalence of infection with Bartonella spp. in a sympatric multi species vole community inhabiting a rural area in north-east Poland. Moreover, we provide evidence that this high prevalence was likely to have been maintained by a significant rate of congenital infections (via transplacental transmission from naturally infected female voles to their offspring). Furthermore, our data indicate that vertical transmission of Bartonella spp. is unlikely to be associated with the successful vertical transmission of the piroplasm B. microti, which was also endemic in these vole populations. Although quite high genetic diversity was identified among the Bartonella sequences (4 species comprised of 5 main genetic clades), the B. taylorii clade B genotype was the most successful in vertical transmission, being the dominant genotype recovered from Bartonella positive embryos and pups.

Our study is among the first to dissect the complex interactions involved in the transmission and circulation of Bartonella spp. among a multi-species sympatric Microtus vole community. We provide novel data to complement our long-term monitoring of Bartonella infections and our earlier work at these same study sites in the Mazury Lake District. The first study on Bartonella in voles from this region was carried out in 1997-2000 [33] and focused on $M$. arvalis. Subsequently, in the period 2004-2006, the second study incorporated $M$. arvalis and $M$. oeconomus populations [13, 14], and then between 2007 and 2009 documented the genetic diversity of bartonellae in these vole species $[15,17]$. Building on these earlier studies in the present paper, we provide an update on the prevalence of Bartonella in more recent years (2013-2014) and focus on the question of why prevalence of Bartonella spp. in this community of three vole species ( $M$. arvalis, $M$. agrestis and $M$. oeconomus) is consistently so high among the youngest animals which are unlikely to have experienced encounters with hematophagous vectors (and hence unlikely to have been infected after birth).

The overall prevalence of Bartonella spp. in this period of 17 years was lowest in the first period ( $28 \%$ in $M$. arvalis [33]). Here we report a much higher prevalence of Bartonella spp. (67\%) in the Microtus community in the period 2013-2014 (73\% in M. arvalis, 59\% in M. agrestis and $M$. oeconomus). This much higher prevalence (up to four times higher than previously recorded) can be explained primarily by the fact that sampling was undertaken exclusively in late summer, rather than additionally in the spring when prevalence is generally lower, and by the use of a nested PCR technique for the detection of infection. Seasonal variation in prevalence of Bartonella has been reported previously, and prevalence values in late summer and autumn have been found to be at least twice as high as those observed earlier in the year in most studies $[7,23]$, including in our own earlier work on forest rodents $[17,34]$. Nested PCR is a much more sensitive method for the detection of haemoparasites than the single step PCR used earlier, especially in the case of chronic low-level infections [42-44].

It is also possible that this marked increase in the prevalence of Bartonella in the Microtus community and in each vole species may be attributable to changes in the quality and character of the microhabitat affecting vector populations. Fleas are the main vectors of Bartonella spp. among rodents $[7,16,26]$ and the life-cycles of these insects includes a free-living larval stage, which is sensitive to unfavourable abiotic conditions, including heavy rain. In 2013, we studied flea infestations in the vole community and we found that the prevalence of fleas was highest among $M$. arvalis (81\%) inhabiting the dry upper parts of fallow land, and lowest in root voles (68\%) inhabiting the narrow strips surrounding ponds on the grassland, which are often totally submerged during periods of intense rainfall [45]. Additionally, the peak prevalence of Bartonella recorded in 2006 was accompanied by the highest recorded infestation by fleas $(84 \%$ infested rodents in 2006 versus 34\% in 2004) [13]. We suspected that the exceptionally dry summers in 2013 and 2014 could have created conditions that were particularly suitable for the completion of flea life-cycles and, in turn, this has resulted in higher flea infestations and hence more frequent transmission of bartonellae to voles. Some abiotic data (mean water levels in Poland's main river, the Vistula River, and largest lake, Lake Śniardwy in the Mazury Lake District) are presented in Additional file 2: Figure S1, and these support the existence of a dry period since 2012. Unfortunately, there is insufficient data yet to test our hypothesis since no data are available on flea infestation in the period 2000-2009, but this is an issue which the continuation of our studies may resolve in the future.

There are few similar studies on Bartonella in Microtus spp. with which we can directly compare our data. Perhaps the closest was completed on $M$. agrestis in the UK [23] and in this the prevalence of Bartonella spp. in autumn $(58 \%)$ was very similar to that observed in our 
field voles, although in spring prevalence fell to just over half this level (34\%). A similar prevalence was recently found in $M$. arvalis in Slovakia (61\% [21]) but in a related host species from the Russian Far East, Microtus fortis, prevalence of Bartonella was much higher (83\% [10]). Overall, most publications report lower prevalence values than those observed here [6,46-48], but the differences may be the result of the low number of examined voles (5-15 individuals per study) or different season of sampling (most of those studies were conducted in spring-autumn or only in spring). Accordingly, in reported studies DNA extraction was usually performed from tissues rather than blood, which could affect the estimation of Bartonella prevalence. Among rodent species studied in the Mazury Lake District, the highest prevalence of Bartonella has been previously observed in yellow-necked mice Apodemus flavicollis (overall 44-46\%, up to $70 \%$ in autumn; [13, 49]), followed by the prevalence in bank voles $M$. glareolus (39\% [34]).

The main focus of the present study was to test the hypothesis that the perpetuation of Bartonella spp. infections in Microtus hosts is dependent to some extent on vertical transmission, most likely through the transplacental route as supported by the high fraction of PCR-positive embryos found in this study. This idea was inspired by our consistent observation of a 'reversed' age effect in the rodent host, with juvenile individuals more often infected than adults [7, 9, 23]. Indeed, even in the present study this age effect was clearly evident in $M$. arvalis, with the lowest prevalence among mature adults, as in our first study in this area in 1998 and 2000 [33]. Interestingly, in the present study the overall success of vertical transmission of Bartonella spp. (calculated collectively for embryos in and pups born to infected mothers) was very similar in all three host species: $50 \%$ for $M$. arvalis, $52 \%$ for M. oeconomus and $50 \%$ for $M$. agrestis. Comparing these values with the prevalence of Bartonella in juvenile voles (75\%, 40\% and 100\% in $M$. arvalis, $M$. oeconomus and $M$. agrestis, respectively), it is not unreasonable to conclude that the high proportion of Bartonella infections recorded among this youngest age class is likely to have been as a consequence of transmission in utero, through the placental route and hence congenital or vertical in its nature.

Thus, in addition to the well-established vector-borne route of infection, vertical transmission may also act as an important additional mechanism facilitating the circulation of these bacteria in naturally existing rodent populations. Interestingly, although we noted a high rate of transmission to litters (80-100\%) from infected females, not all offspring of infected mothers became infected, with the proportion per litter ranging from 0 to $100 \%$ of the embryos/pups becoming infected. The proportion of litters and embryos/pups from infected females that became infected with Bartonella in the current study corresponds well with findings in some other studies from different geographical regions. In North America, $80 \%$ of litters and $47 \%$ of cotton rat $(S$. hispidus) embryos/newborns tested positive for Bartonella and $100 \%$ of litters and three out of three tested white-footed mouse ( $P$. leucopus) embryos were found to be Bartonella-positive [27]. In the Barcelona region of Spain, $100 \%$ of litters and $69 \%$ of embryos of Bartonella-positive wood mice (A. sylvaticus) were positive [29]. A higher rate of transmission to offspring was recorded in an experimental study in BALB/c mice, with $76 \%$ of fetal resorptions positive for $B$. birtlesi [28] but a much lower success of vertical transmission was found in experimentally infected jirds: only one positive pup out of 15 born to infected dams [26].

The success of vertical transmission of Bartonella may, therefore, depend to some extent on host species, but there is also evidence that it may depend on the species/genotype of bacteria involved. The pioneering study of Kosoy et al. [27], in which several phylogenetic groups of Bartonella were identified by gltA gene sequencing, first provided evidence that the efficiency of congenital transmission varied significantly between Bartonella genotypes. In the study all Bartonella genotypes found in positive embryos/newborns were identical to genotypes in their corresponding mothers, but only two genotypes were successfully transmitted between females and their offspring: genotype $\mathrm{A}$ in cotton rats and genotype $\mathrm{D}$ in white-footed mice [27]. No positive offspring were found in females infected with genotype $C$.

We also genotyped Bartonella by sequence analysis of a short fragment of the rpoB gene, in both females/dams and their corresponding embryos/pups. Four main genetic groups were identified: $B$. taylorii clades A and B, B. grahamii and a $B$. rochalimae-like variant. In five litters born to infected dams, no infected offspring were noted, and among these we identified B. taylorii clade A (2 litters) and B. taylorii clade B (3 cases) (Tables 3 and 4 ). However, as shown in Table 3, there were four B. grahamii infections in females which were not passed on to offspring and only one that was successfully transmitted to offspring. Pertinently, only the B. taylorii clade B was identified among positive pups (Table 4) and overall therefore this genotype was the most successful in exploiting the vertical route of transmission. Based on our findings, for B. grahamii and the B. rochalimae-like variant, vertical transmission is of lesser importance. This conclusion may explain, to some degree, earlier findings of an absence of successful vertical transmission of Bartonella in bank voles [12], which are mainly infected with B. grahamii [34]. Interestingly, the prevalence of B. taylorii in M. agrestis in the UK was high in 
juvenile field voles in autumn, in contrast to $B$. doshiae (which was more prevalent among adults), thus supporting the results of our study [23].

To the best of our knowledge, our study is the first to evaluate the impact of congenital infections of Bartonella in wild rodents on the survival and condition of pups. As in the case of congenital infections with $B$. microti [35], we found no evidence for any negative impact: the mortality rate was similar in Bartonella-positive and negative pups and the mean weights of infected and uninfected pups were also similar. We compared also mean abundance of infection between wild-caught voles and congenitally infected pups. Contrasting patterns were obtained for the two main host species: in common voles, as in the case of $B$. microti infections, the mean abundance of Bartonella spp. was up to ten times higher among adults compared with pups (6.16 iRBC/200 fields versus $0.6 \mathrm{iRBC} / 200$ fields). However, in root voles, the pattern was reversed (mean abundance 0.4 iRBC in wild-caught voles versus $2.5 \mathrm{iRBC}$ in pups). We found no evidence that the success of vertical transmission of Bartonella may be associated with successful vertical transmission of $B$. microti. The exact mechanism of vertical transmission of these pathogens in rodents is not entirely understood; however, in the case of Bartonella, bacteria have been found in cultured placental tissues and lesions [27, 28]. Each of these pathogens may have its own specific mechanism for crossing the placental barrier between female and fetus, but the details of this route of transmission remain to be elucidated. Interestingly, in our earlier study in these same animals, the success of vertical transmission of $B$. microti was higher than the success of transmission of Bartonella spp., reported here, ranging between 70-81\% [35].

Among 113 Bartonella rpoB sequences, the most common species was $B$. taylorii, with clade $B$ genotype more frequently detected than clade A, followed by B. grahamii. Rare genotypes were those of $B$. doshiae and the $B$. rochalimae-like variant. This pattern is observed among other studies of rodent communities in Europe, in which B. taylorii and B. grahamii are profoundly dominant in rodents $[5-7,10]$. It is also evident that $B$. taylorii is genetically the most variable species, and this may be related to adaptation to different host species $[6,15])$. Interestingly, the vast majority of the $r p o B$ sequences recorded in the current work were very similar to genotypes obtained from the same rodent community in earlier surveys in 2007-2009, thus confirming their successful circulation in the rodent populations in this region for at least a decade and likely longer [15, 17, 50]. Additionally, in previous studies in this region $B$. taylorii and $B$. grahamii constituted the great majority of identified Bartonella species/genotypes [13-15, 17, 34]. In $M$. agrestis in the UK, the distribution of Bartonella species/genotypes markedly differed: of the 886 isolates, 264 were B. doshiae, 248 B. grahamii, 324 B. taylorii and 50 of an unidentified Bartonella genotype ("BGA"; [23]). This corresponds to an overall prevalence of $15 \%, 14 \%$, $19 \%$ and 3\% for B. doshiae, B. grahamii, B. taylorii and the "BGA" variant, respectively. So, although B. taylorii was still the most numerous, $B$. doshiae was much more prevalent than in our study.

A relatively rare but distinct genotype that we identified was derived from each of two pups and their mother, which proved to be most similar to B. rochalimae. Although B. rochalimae is believed to infect rodents [2, 7], our phylogenetic analysis clearly showed that together with a Bartonella sequence obtained from a bank vole from France ([6]; a sequence that was very close to ours but not totally identical) our sequences formed a sister branch to $B$. rochalimae isolates from dogs/humans. Buffet et al. [6] proposed a new species name for this genotype, "Bartonella senartensis", but the full description of this species has not yet been completed. Recently in Slovakia, several isolates of Bartonella from rodents, including seven sequences from Microtus voles, have also been found to be genotypically most similar to $B$. rochalimae [21], but again similarity was relatively low, supporting the existence of a new, rodent-adapted species, that has yet to be comprehensively and formally described.

The final step to complete our study on vertical transmission was to identify and compare the species/genotypes of Bartonella in females and their offspring. Although in the majority of female-offspring sets the same genotypes were discovered, the study also revealed the co-infections of two species/genotypes both in females and offspring and successful transmission of only one genotype. We also noticed occurrence of different genotypes in the female-offspring pair (likely due to the above mentioned co-infections in females) and as a result, the occurrence of different genotypes in a single litter. Thus our results show that mixed infections of Bartonella species/genotypes can occur in adult voles, with the $B$. taylorii genotype more 'detectable' or dominant in adult voles and in offspring. However, the observation that Bartonella species/genotypes differ in the success of vertical transmission or in pathogenicity for rodent hosts, requires further study.

\section{Conclusions}

High prevalence of Bartonella spp. infection maintained in Microtus spp. community is followed by a high rate of vertical transmission of several rodent species of Bartonella in three species of naturally infected voles, $M$. arvalis, $M$. oeconomus and $M$. agrestis. Congenitally acquired Bartonella infection does not affect the survival 
of pups. Co-infection with B. microti does not affect the effectiveness of the vertical transmission of Bartonella in voles. Bartonella taylorii clade B was found to be the dominant species in wild-caught voles, including pregnant females and dams, and in their offspring, and was also found to be the most successful in vertical transmission.

\section{Additional files}

Additional file 1: Table S1. Accession numbers of representative Bartonella spp. 313 bp gene fragment of RNA polymerase $\beta$-subunit $($ rpoB) amplified in this study from blood samples from voles near Urwitałt, north-east Poland, in summer 2013 and summer 2014. (DOCX $18 \mathrm{~kb}$ )

Additional file 2: Figure S1. Mean water level in Lake Śniardwy (a) and in the Vistula River (b) in the period 1999-2014. (DOCX $17 \mathrm{~kb}$ )

\section{Abbreviations}

EDTA: ethylene diamine tetraacetic acid; iRBC: infected red blood cell; ns: not significant; rpoB: the $\beta$ subunit of bacterial RNA polymerase

\section{Acknowledgments}

We thank our colleagues and students who provided insight and expertise that greatly assisted the research and those who helped us in the field work. We thank Mgr Grzegorz Górecki, Dr Jolanta Behnke-Borowczyk, Joanna Gabral, Dr Katarzyna Kisiel and Dr Agnieszka Kloch for their help. Special thanks to Professor Francis S. Gilbert from the University of Nottingham, UK for sharing the statistical software.

\section{Funding}

The study was financially supported by the National Science Centre, Poland grant OPUS no. 2011/03/B/NZ8/02212.

\section{Availability of data and materials}

All relevant data are included with in the article and its additional files.

\section{Authors' contributions}

$K T$ and $A B$ designed the study, performed laboratory and statistical analyses. $K T, A B, M K, M A, D D, M G$ and JMB participated in laboratory and field work, and drafted the manuscript. All authors read and approved the final manuscript.

\section{Ethics approval}

All of the procedures were conducted with the approval of the First Warsaw Local Ethics Committee for Animal Experimentation in Poland (ethical license numbers 148/2011 and 406/2013) according to the principles governing experimental conditions and care of laboratory animals required by the European Union and the Polish Law on Animal Protection.

\section{Consent for publication}

Not applicable.

\section{Competing interests}

The authors declare that they have no competing interests.

\section{Publisher's Note}

Springer Nature remains neutral with regard to jurisdictional claims in published maps and institutional affiliations.

\section{Author details}

'Department of Parasitology, Institute of Zoology, Faculty of Biology, University of Warsaw, 1 Miecznikowa Street, 02-096 Warsaw, Poland. ${ }^{2}$ Department of Tropical Parasitology, Institute of Maritime and Tropical Medicine in Gdynia, Medical University of Gdansk, Powstania Styczniowego
9, 81-512 Gdynia, Poland. ${ }^{3}$ School of Life Sciences, University of Nottingham, University Park, Nottingham NG7 2RD, UK.

Received: 9 April 2018 Accepted: 1 August 2018

Published online: 30 August 2018

\section{References}

1. Birtles RJ. Bartonellae as elegant hemotropic parasites. Ann N Y Acad Sci. 2005:1063:270-9.

2. Breitschwerdt EB. Bartonellosis, One Health and all creatures great and small. Vet Dermatol. 2017;28:96-e21.

3. Chaloner GL, Harrison TG, Birtles RJ. Bartonella species as a cause of infective endocarditis in the UK. Epidemiol Infect. 2013;141:841-6.

4. Edouard S, Nabet C, Lepidi H, Fournier PE, Raoult D. Bartonella, a common cause of endocarditis: a report on 106 cases and review. J Clin Microbiol. 2015;53:824-9.

5. Buffet JP, Kosoy M, Vayssier-Taussat M. Natural history of Bartonella-infecting rodents in light of new knowledge on genomics, diversity and evolution. Future Microbiol. 2013;8:1117-28.

6. Buffet JP, Pisanu B, Brisse S, Roussel S, Felix B, Halos L, et al. Deciphering Bartonella diversity, recombination, and host specificity in a rodent community. PLoS One. 2013:8:e68956.

7. Gutierrez R, Krasnov B, Morick D, Gottlieb Y, Khokhlova IS, Harrus S. Bartonella infection in rodents and their flea ectoparasites: an overview. Vector Borne Zoonotic Dis. 2015;15:27-39.

8. Birtles RJ, Harrison TG, Saunders NA, Molyneux DH. Proposals to unify the genera Grahamella and Bartonella, with descriptions of Bartonella talpae comb. nov., Bartonella peromysci comb. nov., and three new species, Bartonella grahamii sp. nov., Bartonella taylorii sp. nov., and Bartonella doshiae sp. nov. Int J Syst Bacteriol. 1995;45:1-8.

9. Kosoy M, Mandel E, Green D, Marston E, Childs J. Prospective studies of Bartonella of rodents. Part I. Demographic and temporal patterns in population dynamics. Vector Borne Zoonotic Dis. 2004:4:285-95.

10. Mediannikov O, Ivanov L, Zdanovskaya N, Vysochina N, Fournier PE, Tarasevich I, et al. Molecular screening of Bartonella species in rodents from the Russian Far East. Ann N Y Acad Sci. 2005;1063:308-11.

11. Kosoy M, Mandel E, Green D, Marston E, Jones D, Childs J. Prospective studies of Bartonella of rodents. Part II. Diverse infections in a single rodent community. Vector Borne Zoonotic Dis. 2004;4:296-305.

12. Bown KJ, Bennet M, Begon M. Flea-borne Bartonella grahamii and Bartonella taylorii in bank voles. Emerg Infect Dis. 2004;10:684-7.

13. Welc-Faleciak R, Bajer A, Behnke JM, Sinski E. The ecology of Bartonella spp. infections in two rodent communities in the Mazury Lake District region of Poland. Parasitology. 2010;137:1069-77.

14. Welc-Faleciak R, Paziewska A, Bajer A, Behnke JM, Sinski E. Bartonella spp. infection in rodents from different habitats in the Mazury Lake District, Northeast Poland. Vector Borne Zoonotic Dis. 2008;8:467-74.

15. Paziewska A, Harris PD, Zwolinska L, Bajer A, Sinski E. Recombination within and between species of the alpha proteobacterium Bartonella infecting rodents. Microb Ecol. 2011;61:134-45.

16. Morick D, Krasnov BR, Khokhlova IS, Gottlieb Y, Harrus S. Investigation of Bartonella acquisition and transmission in Xenopsylla ramesis fleas (Siphonaptera: Pulicidae). Mol Ecol. 2011;20:2864-70.

17. Paziewska A, Harris PD, Zwolinska L, Bajer A, Sinski E. Differences in the ecology of Bartonella infections of Apodemus flavicollis and Myodes glareolus in a boreal forest. Parasitology. 2012;139:881-93.

18. Bai Y, Calisher CH, Kosoy MY, Root JJ, Doty JB. Persistent infection or successive reinfection of deer mice with Bartonella vinsonii subsp. arupensis. Appl Environ Microb. 2011;77:1728-31.

19. Bai Y, Kosoy MY, Lerdthusnee K, Peruski LF, Richardson JH. Prevalence and genetic heterogeneity of Bartonella strains cultured from rodents from 17 provinces in Thailand. Am J Trop Med Hyg. 2009;81:811-6.

20. Silaghi C, Pfeffer M, Kiefer D, Kiefer M, Obiegala A. Bartonella, rodents, fleas and ticks: a molecular field study on host-vector-pathogen associations in Saxony, eastern Germany. Microb Ecol. 2016;72:965-74.

21. Spitalska E, Minichova L, Kocianova E, Skultety L, Mahrikova L, Hamsikova Z, et al. Diversity and prevalence of Bartonella species in small mammals from Slovakia, central Europe. Parasitol Res. 2017:116:3087-95.

22. Alsarraf M, Mohallal EME, Mierzejewska EJ, Behnke-Borowczyk J, WelcFaleciak R, Bednarska M, et al. Description of Candidatus Bartonella fadhilae n. sp. and Candidatus Bartonella sanaae n. sp. (Bartonellaceae) from 
Dipodillus dasyurus and Sekeetamys calurus (Gerbillinae) from the Sinai Massif (Egypt). Vector Borne Zoonotic Dis. 2017;17:483-94.

23. Telfer S, Begon M, Bennett M, Bown KJ, Burthe S, Lambin X, et al. Contrasting dynamics of Bartonella spp. in cyclic field vole populations: the impact of vector and host dynamics. Parasitology. 2007;134:413-25.

24. Billeter SA, Levy MG, Chomel BB, Breitschwerdt EB. Vector transmission of Bartonella species with emphasis on the potential for tick transmission. Med Vet Entomol. 2008;22:1-15.

25. Tsai YL, Chang CC, Chuang ST, Chomel BB. Bartonella species and their ectoparasites: selective host adaptation or strain selection between the vector and the mammalian host? Comp Immunol Microb. 2011;34: 299-314.

26. Morick D, Krasnov BR, Khokhlova IS, Gottlieb Y, Harrus S. Transmission dynamics of Bartonella sp. strain OE 1-1 in Sundevall's jirds (Meriones crassus). Appl Environ Microb. 2013:79:1258-64.

27. Kosoy MY, Regnery RL, Kosaya OI, Jones DC, Marston EL, Childs JE. Isolation of Bartonella spp. from embryos and neonates of naturally infected rodents. J Wildl Dis. 1998;34:305-9.

28. Boulouis HJ, Barrat F, Bermond D, Bernex F, Thibault D, Heller R, et al. Kinetics of Bartonella birtlesii infection in experimentally infected mice and pathogenic effect on reproductive functions. Infect Immun. 2001;69:5313-7.

29. Cevidanes A, Altet L, Chirife AD, Proboste T, Millan J. Drivers of Bartonella infection in micromammals and their fleas in a Mediterranean peri-urban area. Vet Microbiol. 2017;203:181-8.

30. Breitschwerdt EB, Maggi RG, Farmer P, Mascarelli PE. Molecular evidence of perinatal transmission of Bartonella vinsonii subsp. berkhoffii and Bartonella henselae to a child. J Clin Microbiol. 2010;48:2289-93.

31. Velho PE, Bellomo-Brandao MA, Drummond MR, Magalhaes RF, Hessel G, Barjas-Castro M, et al. Bartonella henselae as a putative cause of congenital cholestasis. Rev Inst Med Trop Sao Paulo. 2016;58:56.

32. Tuya XL, Escalante-Kanashiro R, Tinco C, Pons MJ, Petrozzi V, Ruiz J, et al. Possible vertical transmission of Bartonella bacilliformis in Peru. Am J Trop Med Hyg. 2015;92:126-8.

33. Pawelczyk A, Bajer A, Behnke JM, Gilbert FS, Sinski E. Factors affecting the component community structure of haemoparasites in common voles (Microtus arvalis) from the Mazury Lake District region of Poland. Parasitol Res. 2004;92:270-84.

34. Bajer A, Welc-Faleciak R, Bednarska M, Alsarraf M, Behnke-Borowczyk J, Sinski $\mathrm{E}$, et al. Long-term spatiotemporal stability and dynamic changes in the haemoparasite community of bank voles (Myodes glareolus) in NE Poland. Microb Ecol. 2014;68:196-211.

35. Tolkacz K, Bednarska M, Alsarraf M, Dwuznik D, Grzybek M, Welc-Faleciak R, et al. Prevalence, genetic identity and vertical transmission of Babesia microti in three naturally infected species of vole, Microtus spp. (Cricetidae). Parasit Vectors. 2017;10:66.

36. Pucek Z. Keys to Vertebrates of Poland. Mammals. Warszawa: PWN; 1981.

37. Renesto P, Gouvernet J, Drancourt M, Roux V, Raoult D. Use of rpoB gene analysis for detection and identification of Bartonella species. J Clin Microbiol. 2001:39:430-7.

38. Behnke JM, Bajer A, Harris PD, Newington L, Pidgeon E, Rowlands G, et al. Temporal and between-site variation in helminth communities of bank voles (Myodes glareolus) from N.E. Poland. 1. Regional fauna and component community levels. Parasitology. 2008;135:985-97.

39. Behnke JM, Bajer A, Harris PD, Newington L, Pidgeon E, Rowlands G, et al. Temporal and between-site variation in helminth communities of bank voles (Myodes glareolus) from N.E. Poland. 2. The infracommunity level. Parasitology. 2008;135:999-1018.

40. Grzybek M, Bajer A, Bednarska M, Al-Sarraf M, Behnke-Borowczyk J, Harris $\mathrm{PD}$, et al. Long-term spatiotemporal stability and dynamic changes in helminth infracommunities of bank voles (Myodes glareolus) in NE Poland. Parasitology. 2015;142:1722-43.

41. Rohlf FJ, Sokal RR. Statistical Tables. San Francisco: Freeman W.H. \& Company; 1995.

42. Lebech AM, Clemmensen O, Hansen K. Comparison of in vitro culture, immunohistochemical staining, and PCR for detection of Borrelia burgdorferi in tissue from experimentally infected animals. J Clin Microbiol. 1995;33: 2328-33.

43. Takahashi S, Takahashi T, Kuragano T, Nagura Y, Fujita T, Nakayama T, et al. A case of chronic renal failure complicated with tuberculous meningitis successfully diagnosed by nested polymerase chain reaction (PCR). Nihon Jinzo Gakkai Shi. 2005;47:113-20 (In Japanese).
44. von Stedingk LV, Olsson I, Hanson HS, Asbrink E, Hovmark A. Polymerase chain reaction for detection of Borrelia burgdorferi DNA in skin lesions of early and late Lyme borreliosis. Eur J Clin Microbiol Infect Dis. 1995;14:1-5.

45. Bajer A, Cynowska K, Juśko M, Tołkacz K, Alsarraf M, Grzybek M, Bednarska $\mathrm{M}$, Behnke JM. Tick and flea communities in three sympatric populations of voles (Microtus spp.) from the Mazury Lake District. In: 16th International Symposium 'Parasitic and allergic arthropods- medical and sanitary significance: 2-4 June 2014; Kazimierz Dolny, Poland; 2014. p. 19-20.

46. Tadin A, Tokarz R, Markotic A, Margaletic J, Turk N, Habus J, et al. Molecular survey of zoonotic agents in rodents and other small mammals in Croatia. Am J Trop Med Hyg. 2016;94:466-73.

47. Malania L, Bai Y, Osikowicz LM, Tsertsvadze N, Katsitadze G, Imnadze P, et al. Prevalence and diversity of Bartonella species in rodents from Georgia (Caucasus). Am J Trop Med Hyg. 2016;95:466-71.

48. Schmidt S, Essbauer SS, Mayer-Scholl A, Poppert S, Schmidt-Chanasit J, Klempa B, et al. Multiple infections of rodents with zoonotic pathogens in Austria. Vector Borne Zoonotic Dis. 2014;14:467-75.

49. Paziewska A. Diversity of blood parasites of genus Bartonella in wild rodents in Mazury Lakes District. Warsaw: PhD Thesis, University of Warsaw; 2010.

50. Paziewska A, Zwolinska L, Harris PD, Bajer A, Sinski E. Utilisation of rodent species by larvae and nymphs of hard ticks (Ixodidae) in two habitats in NE Poland. Exp Appl Acarol. 2010:50:79-91.

\section{Ready to submit your research? Choose BMC and benefit from:}

- fast, convenient online submission

- thorough peer review by experienced researchers in your field

- rapid publication on acceptance

- support for research data, including large and complex data types

- gold Open Access which fosters wider collaboration and increased citations

- maximum visibility for your research: over $100 \mathrm{M}$ website views per year

At BMC, research is always in progress.

Learn more biomedcentral.com/submissions 